\section{Contents of this Issue}

\section{Artlcles}

E. Frevert: A New Method for Non Contacting Gauging of the Wall Thickness of Steel Tubes with Radioactive Isotopes ....... 301

M. Glaeser, D. Steuer, G.Zobel: A Radiometric Conveyor-Type Weigher with Computer Circuit for Signal Processing .......... 306

L. Gonsyorovsky, T. Kvasnevsky: A NonLinear Filter for Stochastic Signals (in Russian) .................... 311

P. Langner, P. Kleinert: Problems in the Production of ${ }^{113 \mathrm{~m}}$ In Colloid after Application of a Modified ${ }^{109} \mathrm{Sn} /{ }^{113} \mathrm{~m}$ In Generator .. 313

V.M. Petriyev, V.I.Stepchenkov, D.G. Khatchirov: Physico-Chemical Properties of Labelled Albumin Microspheres Yielded by Neutron Activation (in Russian) ....... 315

E. Dobreva, N. Nenoff, B. Zhuikov: Independent Yields of Iodine and Tellurium Isotopes in Fission of ${ }^{232} \mathrm{Th}$ with $30.5 \mathrm{MeV}$ Alpha Particles (in English) ......... 318

S. Trebeljahr, D. Nebel: Simultaneous Polarographic Determination of Uranium and Plutonium ..................... 321

K. Gloe, A. I. Kholkin, P. Mueh', L. M.Gindin: The Distribution of n-Caprylic Acid over Organic Solvents and Aqueous Sodium. Sulphate Solution ................ 324

A. Cecal: Radiochemical Investigation of the Corrosion of Carbon Steel OL-32 in Various Reagents ..................... 328

E. Miơurová, T.Szabová, J.Suliová: The Deoxyribonucleoproteide Changes and Intranuclear DNA and RNA Synthesis in Rat Liver after Irradiation and Partial Hepatectomy (in Russian) ............ 332

M.Gaber, P. Jugelt: Examination to Calculate the Depth of the Primary Ionization of Binary Thick Alloy Systems Caused by Electrons up to $30 \mathrm{keV}$. Part I ........ 336

\section{Letters to the Editor}

A. Kolbe, M. Becker, A. Unverricht, H.R. Schuette: Synthesis of Radioactively Labelled Compounds. Part 47. Production of 2-(2,4-Dichorophenoxy)-Isobutyric Acid${ }^{\left({ }^{4} \mathrm{CH}_{3}\right) \ldots \ldots \ldots \ldots \ldots \ldots \ldots \ldots \ldots \ldots}$

Information 345

New Books 346

\section{Festkörperphysik}

\section{Von KONRAD KREHER}

(Wissenschaftliche Taschenbücher, Reihe Mathematik/Physik)

2. Auflage 1976. 223 Seiten - 122 Abbildungen kl. $8^{\circ}-12,50 \mathrm{M}$

Bestell-Nr. 7615643 (71 03)

In dem Buch werden die Grundlagen der Festkörperphysik dargestellt, d. h., es werden Methoden erläutert, wie man die makroskopischen Eigenschaften kristalliner Festkörper aus ihrem atomaren Aufbau heraus verständlich machen bzw. berechnen kann. Die UUberlegungen werden anhand einfacher (meist eindimensionaler) Modelle ausgeführt, wichtige Experimente im Prinzip (ohne technische Details) erläutert. Voraussetzungen zum Verständnis sind Grundlagenkenntnisse der Experimentalphysik (etwa im Umfang einer einjährigen Vorlesung) und der Quantenphysik (im wesentlichen WelleTeilchen-Dualismus und Atombau).

Bestellungen durch eine Buchhandlung erbeten

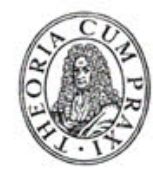

AKA DE M IE-VER LA G

DDR-1080 Berlin, Leipziger Str. 3-4 